Faadilah, et al/Jurnal Ekonomi Syariah Teori dan Terapan Vol. 6 No. 1 Januari 2019: 114-124; FAKTOR INTERNAL YANG BERPENGARUH TERHADAP KINERJA REKSADANA SYARIAH DI INDONESIA PERIODE 20142017

\title{
FAKTOR INTERNAL YANG BERPENGARUH TERHADAP KINERJA REKSADANA SYARIAH DI INDONESIA PERIODE 2014-2017
}

\section{Farah Faadilah}

Mahasiswa Program Studi S1 Ekonomi Islam Fakultas Ekonomi dan Bisnis Universitas Airlangga Email: farah.faadilah-2014@feb.unair.ac.id

\section{Puji Sucia Sukmaningrum}

Departemen Ekonomi Syariah Fakultas Ekonomi dan Bisnis Universitas Airlangga Email: puji.sucia@feb.unair.ac.id

\begin{abstract}
:
This study aims to determine the effect of fund size, expense ratio and turnover ratio. The data used in this research is the net asset value data and shariah mutual fund prospectuses of four shariah equity funds for the period 2013-2017. This study used multiple linear regression tests to prove the relationship between exogenous and endogenous variables. The results showed that partially fund size have insignificant and positive effect on the performance of Islamic stock mutual funds, the expense ratio has insignificant and negative effect on the performance of Islamic equity mutual funds, while the turnover ratio has a significant and positive effect on the performance of sharia mutual funds. While simultaneously fund size, expense ratio and turnover ratio have a significant influence with the coefficient of determination of $83 \%$ while the remaining $17 \%$ influenced by other variables not included in this study.
\end{abstract}

Keywords: Sharia Mutual Funds Performance, Turnover Ratio, Cash Flow, Expense Ratio

\section{PENDAHULUAN}

\section{Latar Belakang}

Setiap manusia memerlukan harta untuk mencukupi kebutuhan hidupnya baik dimasa sekarang maupun dimasa mendatang. Karena itulah manusia akan selalu berusaha memperoleh harta tersebut. Salah satunya yaitu melalui kegiatan investasi. Investasi sendiri merupakan penempatan sejumlah dana pada saat ini dengan harapan memperoleh keuntungan dimasa yang akan datang (Tandelilin, 2001:3). Pada prinsipnya investasi adalah kita sisihkan vang sekarang, kita taruh untuk menghasilkan sesuatu dimasa depan yang jumlahnya lebih banyak dari sekarang.
Islam mendorong setiap manusia untuk bekerja dan meraih sebanyakbanyaknya materi. Islam membolehkan setiap manusia mengusahakan harta sebanyak yang ia mampu, mengembangkan, memanfaatkan sepanjang tidak melanggar ketentuan agama (Yuliana, 2010:9). Investasi sendiri merupakan salah satu ajaran dari konsep islam. Hal tersebut dijelaskan dalam dalam al-Quran Surah al baqarah ayat 261 sebagai berikut :

Artinya: Perumpamaan (nafkah yang dikeluarkan oleh) orang-orang yang menafkahkan hartanya di jalan Allah adalah serupa dengan sebutir benih yang menumbuhkan tujuh bulir, pada tiap-tiap bulir seratus biji. Allah melipat gandakan (ganjaran) bagi siapa yang Dia

1) Jurnal ini merupakan bagian dari Skripsi Farah Faadilah, NIM: 041411433006, yang diuji pada tanggal26 Juli 2018 
Faadilah, et al/Jurnal Ekonomi Syariah Teori dan Terapan Vol. 6 No. 1 Januari 2019: 114-124; FAKTOR INTERNAL YANG BERPENGARUH TERHADAP KINERJA REKSADANA SYARIAH DI INDONESIA PERIODE 20142017

kehendaki. dan Allah Maha Luas (karuniaNya) lagi Maha mengetahui.

Berdasarkan data Statistik Reksadana Syariah yang dipublikasi oleh Otoritas Jasa Keuangan (OJK) tahun 2016, jumlah Nilai Aktiva Bersih (NAB) Reksadana Syariah pada tahun 2013 sebesar 9432,19miliar rupiah, terjadi peningkatan hingga tahun 2017 NAB Reksadana Syariah sebesar 28.311,77 miliar rupiah. Reksadana Syariah dari tahun ke tahun menunjukkan tren jumlah NAB yang meningkat, sehingga Reksadana Syariah dapat disimpulkan mampu menarik minat para investor dengan perkembangan yang positif.

Para investor dalam berinvestasi di reksadana syariah tentu saja mengharapkan tingkat pengembalian yang menguntungkan. Terdapat tiga pengukuran kinerja portofolio yang dikembangkan oleh William Sharpe, Jack Treynor dan Michael Jensen. Dalam penelitian ini ukuran kinerja yang akan digunakan adalah metode Sharpe, yang memiliki tujuan untuk mengukur sejauh mana diversifikasi portofolio kombinasi yang optimal dapat menghasilkan keuntungan dengan risiko tertentu.

Ukuran (size) reksa dana dapat dilihat dari besarnya total NAB. Semakin besar ukuran aset yang dikelola akan memberikan fleksibilitas, meningkatkan bargaining power serta memudahkan terciptanya economies of scale yang dapat berdampak pada penurunan biaya sehingga akan berdampak positif terhadap kinerja (Gallagher, 1988).
Expense ratio adalah salah satu rasio keuangan yang menunjukkan seberapa mahal suaru reksadana yang dikelolah oleh manajer investasi. Untuk mendapatkan informasi pasar, manajer investasi membutuhkan biaya yang besar, hal ini dikarenakan mahalnya biaya transaksi dan registrasi efek. Tingginya expense ratio menunjukkan tingginya aktivitas penjualan dan pembelian portofolio untuk mengantisipasi perubahan pasar.

Turnover ratio merupakan rasio perbandingan antara pembelian atau penjualan portofolio dengan rata-rata nilai $N A B$ dalam satu tahun. Turnover ratio dapan menjadi ukuran seberapa agresif manajer investasi dalam memerjualbelikan portofolio. Reksadana dengan turnover rate yang tinggi akan meningkatkan biaya transaksi sehingga dapat mengurangi return.

Rumusan masalah dalam penelitian ini adalah "Pengaruh Fund Size dan Expense ratio, Turnover Ratio Kinerja Reksadana Saham Syariah Periode 20142017 di Indonesia"

Tujuan penelitian ini adalah untuk mengetahui pengaruh Fund size dan Expense ratio, Turnover Ratio dan variabel makro ekonomi sebagai variabel kontrol Kinerja Reksadana Saham Syariah Periode 2014-2017 di Indonesia.

\section{LANDASAN TEORI DAN PENGEMBANGAN HIPOTESIS}

Reksadana syariah adalah reksadana yang beroperasi menurut ketentuan dan prinsip syariah islam, baik 
dakam bentuk akad antara pemodal sebagai pemilik harta (sahib al-mal/rabb al-mal) dengan manajer investasi sebagai wakil sahib al-mal, maupun antara manajer investasi sebagai wakil sahib almal dengan pengguna investasi( Fatwa DSN No.20/DSN-MUI/IX/2000).

Pengukuran terhadap kinerja reksadana penting dilakukan oleh investor sebelum melakukan investasi. Menurut Sharpe (1981:521), dalam melakukan pengukuran kinerja reksadana terdapat dua unsur penting yang harus dipertimbangkan, yaitu tingkat return dan tingkat risiko. Dengan mengukur kinerja reksadana investor dapat mengetahui apakah tingkat return yang dibentuk dapat melebihi return reksadana lainnya yang dijadikan patok duga (benchmark).

Menurut Tandelilin (2010:494), metode Sharpe mendasarkan perhitungannya pada konsep garis pasar modal (capital market line) sebagai patok duga, yaitu dengan cara membagi premi risiko portofolio dengan standar deviasinya. Dengan demikian, metode Sharpe akan bisa dipakai untuk mengukur premi risiko untuk setiap unit risiko pada portofolio tersebut. Secara matematis standar deviasi portofolio reksadana dapat dihitung sebagai berikut:

$$
\sigma=\sqrt{\sigma^{2}}=\sqrt{\frac{\sum(n i-R)^{2}}{n-1}}
$$

Fund size atau ukuran dana adalah besarnya total asset atau total dana kelolaan yang dimiliki oleh suatu reksadana. Ukuran besar kecilnya reksadana dilihat dari Nilai Aktiva Bersih.
Semakin besar total asset atau total dana kelolaannya maka semakin besar ukuran dana perusahaan tersebut.Semakin besar ukuran aset yang dikelola akan memberikan fleksibilitas, meningkatkan bargaining power serta memudahkan terciptanya economies of scale yang dapat berdampak pada penurunan biaya sehingga akan berdampak positif terhadap kinerja (Gallagher, 1988)

Expense ratio adalah perbandingan beban operasional dengan rata-rata Nilai Aktiva Bersih (NAB) dalam satu tahun. Jika jumlah beban menunjukkan kurang dari 1 tahun maka beban tersebut harus dikalikan dengan 12 (jumlah bulan dalam satu tahun) kemudian dibagi dengan jumlah bulan dalam periode tersebut. Expense ratio menunjukkan seberapa efisien manajer investasi dalam mengelola suatu reksadana.

$$
\frac{\text { Beban investasi }}{\text { Rata - rata NAB }}
$$

Turnover ratio adalah rasio perbandingan antara penjualan atau pembelian dalam satu tahun (dilihat mana yang paling rendah)dengan atarata Nilai Aktiva Bersih dalam satu tahun (Rudiyanto, 2013:92). Turnover ratio menunjukkan seberapa agresif manajer investasi dalam memperjual belikan portofolionya. Reksadana yang dikelolah secara agresif cenderung memiliki turnover ratio yang tinggi. Tingginya aktivitas penjualan dan pembelian dapat menyebabkan tingginya biaya operasional. 
Penjualan/Pembelian yang terkecil

$$
\text { Rata - rata NAB }
$$

Nilai tukar atau yang biasa dikenal sebagai kurs adalah nilai satuan mata vang dalam satuan mata uang lain. Nilai mata uang ditentukan oleh pasar valuta asing yang merupakan tempat berbagai mata vang yang berbeda diperdagangkan (Samuelson dan Nordhaus, 2004:305).

Secara umum Jumlah vang beredar (JUB) adalah uang yang berada di tangan masyarakat, dengan kata lain vang fisik yang dipegang oleh masyarakat secara menyeluruh. Adanya peningkatan beredar akan mendorong bertambahnya sumber pembiayaan bagi perusahaan sehingga perusahaan dapat melebarkan ekspansi usahanya lebih luas yang akhirnya meningkatkan kinerja perusahaan. Meningkatnya kinerja perusahaan akan merangsang para investor melirik saham perusahaan tersebut sehingga berdampak positif terhadap harga saham.

Dalam situs anggaran departemen keuangan menjelaskan bahwa Indonesian Crude oil Price atau harga minyak mentah dunia adalah harga rata-rata minyak mentah Indonesia di pasar internasional yang dipakai sebagai indikator perhitungan bagi hasil minyak, merupakan basis harga minyak mentah yang digunakan untuk perhitungan APBN ditetapkan sepiap bulan dan dievaluasi setiap semester. Kenaikan harga minyak mentah dunia akan mendorong pemerintah menaikan harga bahan bakar minyak yang akan menyebabkan kenaikan inflasi.

Berdasarkan uraian di atas, hipotesis dalam penelitian ini adalah sebagai berikut:

$\mathrm{H}_{01}$ : Fund size secara parsial tidak berpengaruh signifikan terhadap kinerja reksadana syariah di Indonesia periode 2011-2016.

$\mathrm{H}_{\mathrm{Al}}$ : Fund size secara parsial berpengaruh signifikan terhadap kinerja reksadana syariah di Indonesia periode 2011-2016.

$\mathrm{H}_{02}$ : Expense ratio secara parsial tidak berpengaruh signifikan terhadap kinerja reksadana syariah di Indonesia periode 2011-2016.

$\mathrm{H}_{\mathrm{A} 2}$ : Expense ratiosecara parsial berpengaruh signifikan terhadap kinerja reksadana syariah di Indonesia periode 2013-2017.

H03: Turnover ratiosecara parsial tidak berpengaruh signifikan terhadap kinerja reksadana syariah di Indonesia periode 2013-2017.

$\mathrm{H}_{\mathrm{A} 3}$ : Turnover ratio secara parsial berpengaruh signifikan terhadap kinerja reksadana syariah di Indonesia periode 2013-2017.

$\mathrm{H}_{04}$ : Fund size, Expense ratio, danTurnover ratio. Secara simultan tidak berpengaruh signifikan terhadap kinerja reksadana syariah di Indonesia periode 20132017.

$\mathrm{H}_{\mathrm{A} 4}$ : Turnover ratio, cash flow dan expense ratio secara simultan berpengaruh signifikan terhadap 
kinerja reksadana syariah di Indonesia periode 2013-2017.

Model analisis penelitian sebagai berikut:

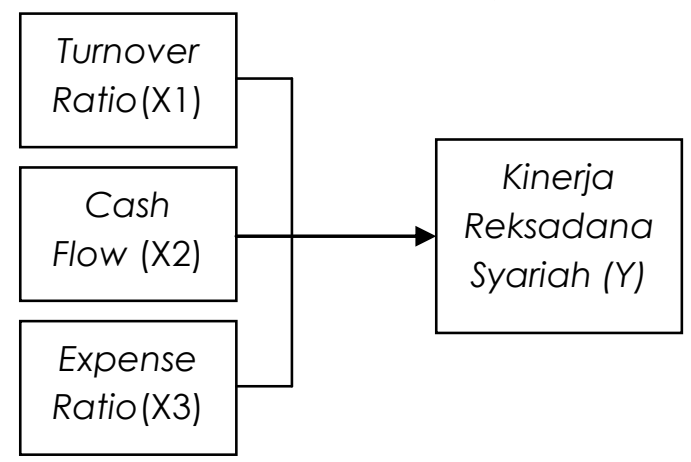

Gambar 1. Model Analisis

\section{METODE PENELITIAN}

\section{Pendekatan Penelitian}

Pendekatan penelitian yang digunakan dalam penelitian ini adalah pendekatan kuantitatif. Pendekatan kuantitatif didefinisikan sebagai suatu proses yang menggunakan langkah-langkah tertentu secara sistematis, teratur, dan terkontrol terhadap variabel yang ingin diketahui (Yusuf, 2014:12). Dengan demikian pendekatan kualitatif adalah metodelogi penelitian yang bertujuan untuk mengukur data penelitian yang menerapkan beberapa bentuk analisis statistik. Pendekatan kuantitatif dipilih karena sesuai dengan penelitian ini indikator yang digunakan adalah dalam bentuk numerik yang kemudian dianalisis menggunakan metode statistik yang tepat.

\section{Definisi Operasional}

Fungsi dari definisi operasional adalah untuk memberikan batasanbatasan dan menghindari kesalahan dalam pemahaman, serta untuk memudahkan para pembaca. Devinisi operasional variabel-variabel dalam penelitian ini adalah sebagai berikut:
1. Kinerja Reksadana Syariah

Kinerja reksadana syariah pada penelitian ini diukur dengan menggunakan indeks sharpe. Indeks ini mendasarkan perhitungannya pada konsep garis pasar modal sebagai patok duga, yaitu dengan cara membagi premi risiko portofolio dengan standar deviasinya (risiko total) (Tandelilin, 2010:494).

2. Fund size atau ukuran dana merupakan besarnya total asset atau total dana kelolaan yang dimiliki oleh suatu reksadana. Ukuran reksadana tercermin dari asset under management dari masing-masing dana. Semakin besar total asset atau total dana kelolaannya maka semakin besar ukuran dana perusahaan tersebut.

3. Expense Ratio adalah besarnya biaya yang dikeluarkan untuk mengoperasikan reksadana oleh perusahaan investasi (vijayakumar 2012:10).

Dengan membandingkan biaya operasional dalam satu tahun dengan rata-rata nilai aktiva bersih dalam satu tahun. Ekspense ratio juga rasio yang menunjukkan seberapa efisien manajer investasi dalam mengelolah reksadana.

4. Turnover Ratio adalah rasio yang menunjukkan intensitas manajer investasi dalam memperjual belikan portofolio dalam investasi reksadana. Manajer investasi dengan pengetahuan yang baik 
akan mampu memperjual belikan portofolio secara konstan, sehingga return reksadana akan lebih tinggi dibandingkan dengan biaya perputaran portofolio.

Data sekunder yang diperlukan dalam penelitian ini meliputi Nilai Aktiva Bersih (NAB), NAB per Unit Penyertaan, beban operasi reksadana, serta perputaran portofolio reksadana serta data variabel makroekonomi. Data ini bersumber dari laporan kevangan yang terdapat dalam prospektus pembaharuan masing-masing perusahaan reksadana syariah, website resmi OJK dan Bank Indonesia.

Populasi pada penelitian ini adalah Reksadana Syariah yang terdaftar di Otoritas Jasa Keuangan. Berdasarkan data dari Otoritas Jasa Keuangan jumlah populasi yaitu 182 reksadana syariah 47 reksadana saham syariah yang terdaftar hingga saat ini.

Teknik pengambilan sampel yang digunakan pada penelitian ini adalah purposive sampling, yaitu penentuan sampel dengan pertimbangan tertentu (Anshori dan Iswati, 2009:105).

Kriteria sampel sebagai berikut:

1. Reksadana yang terdaftar di OJK dan dinyatakan aktif selama periode penelitian 2014-2017.

2. Reksadana berjenis saham syariah.

3. Reksadana yang menerbitkan dan mempublikasikan laporan keuangan dalam prospektus pembaharuan selama periode penelitian.

Berdasarkan kriteria tersebut, maka sampel yang didapatkan sebanyak 4 reksadana saham syariah dan reksadana campuran syariah.

Tabel 1

Daftar Nama Reksadana Syariah

\begin{tabular}{|c|l|}
\hline No. & Reksadana Syariah \\
\hline 1 & Batavia Dana Saham Syariah \\
\hline 2 & BNP Paribas Pesona Syariah \\
\hline 3 & Mandiri Investa Atraktif Syariah \\
\hline 4 & Manulife Syariah Sektoral Amanah \\
\hline
\end{tabular}

\section{Teknik Analisis}

Penelitian ini menggunakan analisis regresi linier berganda untuk menjawab hipotesis yang ada. Uji analisis regresi linier berganda merupakan suatu alat untuk melihat pengaruh dua atau lebih variabel bebas terhadap satu variabel terikat untuk membuktikan ada atau tidak adanya suatu hubungan.

Teknik analisis regresi linier berganda dalam penelitian ini digunakan untuk menguji pengaruh Turnover Ratio $\left(X_{1}\right)$, Cash Flow $\left(X_{2}\right)$ dan Expense Ratio $\left(X_{3}\right)$ terhadap Kinerja Reksadana Syariah di Indonesia (Y).Model persamaan analisis regresi linier berganda adalah sebagai berikut:

$$
Y=a+\beta_{1} X_{1}+\beta_{2} X_{2}+\beta_{3} X_{3}+e
$$

Penelitian yang menggunakan model analisis regresi termasuk kelompok analisis parametrik. Terdapat beberapa persyaratan analisis yang harus dipenuhi sebelum dilakukan pengambilan kesimpulan dari analisis regresi tersebut, yaitu, uji normalitas, uji multikolinieritas dan uji heteroskedastisitas.

Uji statistik † dilakukan untuk mengetahui seberapa jauh masing- 
Faadilah, et al/Jurnal Ekonomi Syariah Teori dan Terapan Vol. 6 No. 1 Januari 2019: 114-124; FAKTOR INTERNAL YANG BERPENGARUH TERHADAP KINERJA REKSADANA SYARIAH DI INDONESIA PERIODE 20142017

masing variabel bebas berpengaruh pada variabel terikat (Baroroh, 2013:3).Uji statistik $F$ dilakukan untuk mengetahui pengaruh variabel-variabel bebas secara simultan terhadap variabel terikat (Baroroh, 2013:2). Koefisien determinasi $\left(R^{2}\right)$ digunakan untuk mengukur seberapa jauh kemampuan variabel bebas dalam menjelaskan keragaman variabel terikat. Semakin besar nilai $R^{2}$, maka variabel bebas semakin dekat hubungannya dengan variabel terikat (Baroroh, 2013:5).

\section{HASIL DAN PEMBAHASAN}

\section{Deskripsi Hasil Penelitian}

1. Deskripsi Kinerja Reksadana Syariah

Kinerja reksadana syariah pada penelitian ini diukur menggunakan metode Sharpe. Unsur penting dalam menimbang kinerja reksadana syariah adalah tingkat return dan tingkat risiko, sehingga penurunan kinerja reksadana syariah yang tinggi dikarenakan return reksadana syariah yang dihasilkan tidak sebanding dengan risiko yang harus ditanggung.

2. Deskripsi Fund size

Semakin besar dana atau aset yang dikelola maka dapat meningkatkan fleksibilitas, dan meningkatkan bargaining power serta memudahkan terciptanya economies of scale yang dapat berdampak pada penurunan biaya sehingga akan berdampak positif terhadap kinerja.

3. Deskripsi Expense Ratio

$$
\text { Manajer Investasi sebagai }
$$
pengelola reksadana bertanggung jawab untuk mengelola dana investasi sehingga nantinya akan menghasilkan pendapatan. Penggunaan dana yang efisien menunjukkan bahwa Manajer Investasi memiliki keahlian yang baik dalam mengelola dana investasi. Sedangkan kenaikan dari tingkat expense ratio menunjukkan bahwa Manajer Investasi kurang mampu menyesuaikan beban yang harus dikeluarkan dengan total aset yang dimiliki reksadana syariah.

4. Deskripsi Turnover Ratio

Semakin tinggi turnover ratio menandakan perputaran portofolio yang semakin cepat, sehingga Manajer Investasi dapat dikatakan aktif dan agresif dalam mengelola portofolio reksadana syariah.Dalam upaya menghindari risiko, seorang Manajer Investasi akan melakukan jual beli atau transaksi portofolio lebih banyak untuk mengantisipasi perubahan pasar.

\section{Uji Persyaratan Analisis Regresi}

1. Uji Normalitas

Hasil uji normalitas menggunakan analisis grafik Normal Probability Plotmenunjukkan bahwa titik-titik menyebar disekitar garis diagonal dan mengikuti arah garis yaitu dari bawah ke atas. Maka dapat disimpulkan bahwa uji normalitas menggunakan Normal Probability Plot menunjukkan data berdistribusi normal. 


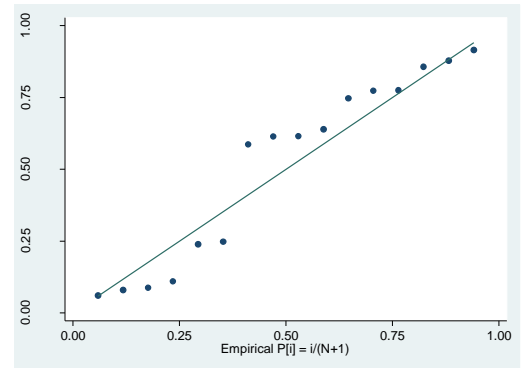

Sumber : Hasil olah data stata 14

\section{Gambar 2. Hasi Uji Normalitas}

2. Uji Multikolinearitas

Uji multikonieritas digunakan untuk menguji apakah di dalam model regresi terdapat hubungan atau korelasi antar variabel bebas.

Tabel 2.

\begin{tabular}{|l|c|c|}
\hline \multicolumn{1}{|c|}{ Variabel } & VIF & $1 / \mathrm{VIF}$ \\
\hline Fund Size & 1.15 & 0.866 \\
\hline Expense & 1.16 & 0.861 \\
\hline turnover & 1.02 & 0.976 \\
\hline
\end{tabular}

Sumber : Hasil olah data stata 14

Hasil uji multikolinearitas menunjukkan bahwa nilai VIF dari masing masing variabel menunjukkan dibawah 10 dan nilai tolerance dari masing masing variabel diatas 0,1 dan nilai mean VIF dibawah 10 sehingga model regresi menunjukkan tidak adanya multikolinearitas.

3. Uji Heteroskedastisitas

Hasil uji heterokedasititas menujukan bahwa titik menyebar dibawah dan diatas 0 dan tidak membentuk pola tertentu. Sehingga dapat disimpulkan model regresi linier, varian antar grup sama. Dengen demikian maka hasil uji heterokedastisitas menujukkan bahwa model regresi adalah homokedastisitas atau tidak heterokedastisitas.

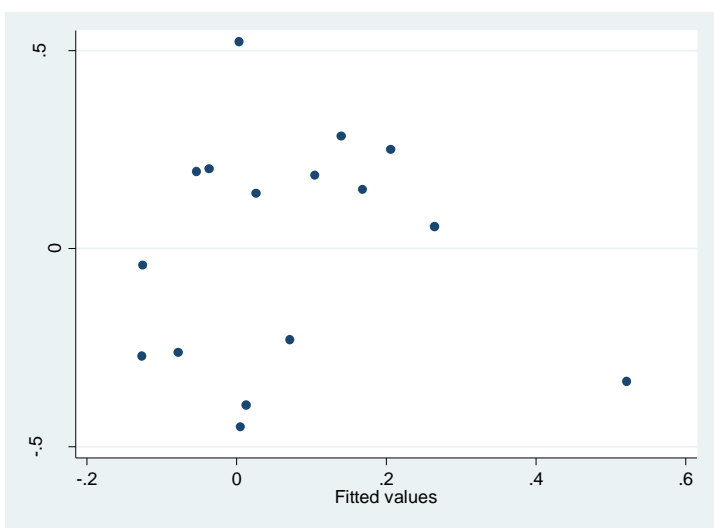

Sumber : Hasil olah stata 14

Gambar 3. Hasil Uji Heteroskedastisitas

Analisis Regresi Linier Berganda

Tabel 3.

Hasil Analisis Regresi Linier Berganda

\begin{tabular}{|c|c|c|c|}
\hline \multirow{2}{*}{ Model } & \multicolumn{2}{|c|}{$\begin{array}{c}\text { Unstandardize } \\
\text { Coefficient }\end{array}$} & \multirow{2}{*}{$\begin{array}{c}\text { Stand. } \\
\text { coef }\end{array}$} \\
\cline { 2 - 3 } & B & $\begin{array}{l}\text { Std. } \\
\text { Error }\end{array}$ & \\
\hline Constant & -0.390 & 3.446 & \\
\hline Fund Size & 0.015 & 0.119 & 0.005 \\
\hline $\begin{array}{l}\text { Expanse } \\
\text { Turnover }\end{array}$ & 0.041 & 11.625 & 1.323 \\
& 0.494 & 0.413 & 0.754 \\
\hline
\end{tabular}

Sumber : Hasil olah statal 4

Nilai konstanta sebesar -0.390 menunjukkan apabila variabel eksogen besarnya nol atau konstan, maka nilai kinerja reksadana saham syariah adalah 0.390 .

Variabel fund size memiliki koefisien regresi sebesar 0.015. Hal ini berarti apabila fund size meningkat satu satuan, maka variabel kinerja reksadana saham syariah juga akan meningkat sebesar 0.015 dan begitu pula sebaliknya dengan asumsi variabel lain konstan.

Variabel expense ratio memiliki koefisien regresi sebesar 0.041. Hal ini berarti apabila kepemilikan expense ratio meningkat satu satuan, maka variabel 
Faadilah, et al/Jurnal Ekonomi Syariah Teori dan Terapan Vol. 6 No. 1 Januari 2019: 114-124; FAKTOR INTERNAL YANG BERPENGARUH TERHADAP KINERJA REKSADANA SYARIAH DI INDONESIA PERIODE 20142017

kinerja saham syariah akan menurun sebesar 0.041 dan begitu pula sebaliknya dengan asumsi variabel lain konstan.

Variabel turnover ratio memiliki koefisien regresi sebesar 0.494 . Hal ini berarti apabila turnover ratio meningkat satu satuan, maka variabel kinerja reksadana saham syariah juga akan meningkat sebesar 0.494dan begitu pula sebaliknya dengan asumsi variabel lain konstan.

\section{Koefisien Determinasi $\left(\mathbf{R}^{2}\right)$}

Berdasarkan hasil uji koefisien determinasi ( $R$ square), diperoleh nilai $R$ square sebesar 0,2506. Dapat disimpulkan bahwa perubahan kinerja reksadana syariah dapat dijelaskan oleh fund size, expense ratio turnover ratio sebesar 0,2506 atau $25.06 \%$, sedangkan sisanya sebesar 0,7494 atau $74.94 \%$ dijelaskan oleh variabel lain yang tidak digunakan dalam penelitian ini.

\section{Pembahasan}

Pengaruh Fund Size Terhadap Kinerja

\section{Reksadana Saham Syariah}

Berdasarkan hasil penelitian, diketahui bahwa Variabel eksogen fund size memliki pengaruh positif tdak signifikan terhadap kinerja reksadana saham syariah. Hal tersebut didapat dari hasil uji $†$ yang menunjukkan nilai signifikansi > dari 0,05 dan nilai † hitung yang lebih kecil dari $\dagger$ tabel. Hal ini sesuai dengan penelitian yang dilakukan oleh Bitomo (2016) yang menunjukkan bahwa fund size memiliki pengaruh positif tidak signifikan terhadap kinerja. Dan menolak teori yang dikemukakan oleh gallager
(1998) Meskipun reksadana dengan size yang besar memiliki economic scale dan kemudahan untuk mendiversifikasi portofio dibandingkan dengan reksadana berukuran kecil. Namun hasil menunjukkan bahwa fund size tidak memiliki pegaruh yang signifikan terhadap kinerja reksadana.

\section{Pengaruh Expense Ratio Terhadap Kinerja} Reksadana Saham Syariah

Berdasarkan hasil penelitian yang telah dilakukan dapat diketahui bahwa variabel eksogen expense ratio memiliki pengaruh negatif tidak signifikan terhadap variabel endogen kinerja reksadana saham syariah. Hal ini dapat diketahui dari nilai signifikansi yang lebih dari 0.05. Dan nilai t hitung yang lebih kecil dari nilai t tabel.

Hal ini berbanding terbalik dengan penelitian yang dilakukan oleh karena dalam reksadana syariah, hal ini terjadi karenadalam reksadana saham syariah manajer invetasi tidak terlalu banyak melakukan transaksi jual beli suoaya terhindar dari maysir hal tersebut menyebabkan rasio beban operasional reksadana tidak terlalu banyak sehingga tidak berpengaruh pada kinerja reksadana saham syariah.

\section{Pengaruh Turnover Tario Terhadap Kinerja} Reksadana Saham Syariah

Berdasarkan hasil penelitian maka dapat diketahui bahwa turnover ratio memiliki pengatuh positif signifikan terhadap variabel endogen kinerja reksadana saham syariah dengan nilai signifikansi yang kurang dari 0.05. serta 
nilai $\dagger$ hitung yang lebih kecil dari nilai $\dagger$ tabel.

Turnover ratio tidak berpengaruh signifikan dikarenakan portofolio turnover merupakan perbandingan nilai antara pembelian dan penjualan portofolio, besarnya nilai perbandingan antara pembelian dan penjualan atau seberapa banyak manajer investasi melakukan penjualan dan pembelian hanya menunjukkan seberapa aktif manajer investasi dalam memperjual belikan asetnya namun tidak mempengaruhi kinerja suatu reksadana. Hal ini sesuai dengan penelitian yang dilakukan oleh Lidyah (2017)

\section{Pengaruh Variabel Kontrol Terhadap}

Kinerja Reksadana Saham Syariah

\section{Simpulan}

Berdasarkan hasil analisis dan uji hipotesis yang telah dilakukan, maka dapat disimpulkan hasil penelitian sebagai berikut :

1. Fund size berpengaruh positif tidak signifikan terhadap kinerja reksadana saham syariah di Indonesia periode 2014-2017 dengan tingkat signifikansi sebesar 0,969 terhadap kinerja reksadana saham syariah. Dengan demikian maka $\mathrm{H}_{01}$ diterima dan $\mathrm{H}_{\mathrm{Al}}$ ditolak.

2. Expense ratio berpengaruh negatif tidak signifikan terhadap kinerja reksadana saham syariah di Indonesia periode 2014-2017 dengan tingkat signifikansi sebesar 0,911 pada kinerja reksadana saham syariah. Dengan demikian hipotesis pada penelitian inimaka $\mathrm{H}_{02}$ diterima dan $\mathrm{H}_{\mathrm{A} 2}$ ditolak

3. Turnover ratio tidak berpengaruh positif signifikan terhadap kinerja reksadana saham syariah di Indonesia periode 2014-2017 dengan tingkat signifikansi sebesar 0,097 pada kinerja reksadana saham syariah. Dengan demikian hipotesis pada penelitian ini maka $\mathrm{H}_{\mathrm{A} 3}$ diterima dan $\mathrm{H}_{03}$ ditolak.

\section{SARAN}

1. Bagi Investor, sebagai investor muslim kita diwajibkan untuk menaati syariat islam dengan memperhatikan kehalalan dalam berinvestasi. Saat ini reksadana syariah memiliki perkembangan yang positif dan mampu bersaing dengan reksadana non syariah.

2. Bagi Manajer Investasi untuk memeperhatikan faktor-faktor yang mempengaruhi kinerja reksadana saham syariah. Reksadana saham syariah sebaiknya tetap memperhatikan turnover ratio, dan expense ratio karena berhubungan dengan beban yang akan ditanggung.

3. bagi peneliti selanjutnya, penelitian ini masih jauh dari kata sempurna sehingga disarankan untuk mengembangkan penelitian ini dengan menambahkan variabel lain serta memperluas jangkauan penelitian dengan meneliti berbagai jenis reksadana syariah yang ada, 
Faadilah, et al/Jurnal Ekonomi Syariah Teori dan Terapan Vol. 6 No. 1 Januari 2019: 114-124; FAKTOR INTERNAL YANG BERPENGARUH TERHADAP KINERJA REKSADANA SYARIAH DI INDONESIA PERIODE 20142017

serta menambahkan periode penelitian .

\section{DAFTAR PUSTAKA}

Baroroh, Ali. 2013. Analisis Multivariat dan

Time Series dengan SPSS 21.

Jakarta: PT Elex Media

Komputindo.

Bitomo, Habib \& Harjum Muharam. 2016.

Analisis Faktor-Faktor yang Mempengaruhi Kinerja Reksa Dana di Indonesia. Diponegoro Journal of Management, Vol. 5, No. 2, hlm. 1-14.

Departemen Agama RI. 2009. Al-Qur'an dan Terjemahnya. Jakarta: Syaamil Quran.

Data Produk Reksadana Syariah per Desember 2016 (www.ojk.go.id, diakses pada 6 April 2018).

Statistik Reksadana Syariah.

Perkembangan Reksadana Syariah per Desember 2016 (www.ojk.go.id, diakses 6 April 2018).

Tandelilin, Eduardus. 2010. Portofolio dan Investasi: Teori dan Aplikasi. Yogyakarta: Kanisius.

Sharpe, William F. 1981. Investments. USA: Prentice Hall.

Yuliana, Indah . 2010 . Investasi Produk Kevangan Syariah. Malang : UIN Maliki Press

www.dsnmui.or.id, diakses pada 28 Februari 2017.

Liitequran, http://litequran.net (diakses tanggal 15 febuari 2018)

www.anggaran.depkeu.go.id (diakses pada 2 April 2018) 